\title{
A comparison of sunshine duration records from the Campbell-Stokes sunshine recorder and CSD3 sunshine duration sensor
}

\author{
Dorota Matuszko
}

Received: 30 June 2013 / Accepted: 6 February 2014 / Published online: 27 February 2014

(C) The Author(s) 2014. This article is published with open access at Springerlink.com

\begin{abstract}
The purpose of this paper is to compare daily sunshine duration data measured using a Campbell-Stokes sunshine recorder (CS) and a CSD3 sunshine duration sensor (AUTO) as well as to attempt to explain discrepancies between the two data sets. The paper is based on heliographic data and cloudiness observations for 2007-2012. All the data come from the research station of the Jagiellonian University located in Krakow, Poland. Both instruments tend to produce similar sunshine duration data; however, the electronic sensor tends to show more sunshine duration than the CS. The difference may amount to several hours a day, especially on days with maximum solar radiation. The CSD3 sensor is twice as sensitive as the CS and reacts quickly to solar radiation. This is especially true for the first hour following sunrise, the last hour before sunset and when the Sun's disc becomes visible for short periods of time due to changes in cloudiness. However, there are days when the CSD3 registers less sunshine duration (up to an hour) than the CS. This happens with Cumulus clouds in the sky, which tend to pass the Sun's disc very quickly. The CSD3 sensor does not register sunshine in the presence of thick Altostratus and Cirrostratus clouds due to the relative lack of direct radiation. The sunshine recorder, on the other hand, registers this low level of sunshine.
\end{abstract}

In recent years, automatic sunshine duration sensors have been replacing the Campbell-Stokes sunshine recorder (CS), which has been in service since the late nineteenth century. The traditional sunshine recorder may have its limitations, but its worldwide acceptance as the chief device for measuring sunshine duration, lasting from 1882 to the beginning of the

D. Matuszko $(\bowtie)$

Department of Climatology, Jagiellonian University,

ul. Gronostajowa 7, 30-387 Krakow, Poland

e-mail: d.matuszko@uj.edu.pl twenty-first century, ensured good comparability of heliographic data (Stanhill 2003). In 1962, the Campbell-Stokes sunshine recorder was adopted by the World Meteorological Organization (WMO) as the Interim Reference Sunshine Recorder (IRSR) to whose standard all sunshine data published worldwide were supposed to be adjusted (World Meteorological Organization 1962). The introduction of automatic sensors created a problem with data comparability and the continuity of heliographic series, since the WMO has not recommended any specific device type. Currently, a range of various automatic devices is being used, including Kipp \& Zonen CSD 3, Haenni Solar 111 and Vaisala DSU12.

Some climatological databases tend not to publish details of the sunshine measurement devices used despite the fact that there is a string association between the type of device used and the recorded values. Not all data users realise that a change in the sunshine measurement device can break the continuity of a data series thus leading to inaccurate conclusions about the long-term variability of the particular climate element. Indeed, each use of records from automatic climate sensors should involve an analysis comparing these data with data obtained using traditional methods. The World Meteorological Organization (2008) requires that results from new types of devices be verified over long periods, i.e. at least 1 year.

The goal of the present study is to compare daily sunshine duration values from the Campbell-Stokes sunshine recorder and the Kipp \& Zonen CSD3 sunshine duration sensor and to attempt to explain the causes of differences. The paper also serves as a contribution to the debate on methodological uncertainty regarding the homogeneity of climatological data series used for climate change analyses.

The CSD3 sunshine duration sensor and the CampbellStokes sunshine recorder employ radically different designs and measurement principles. The latter instrument uses a direct optical method using the heat energy of the Sun's direct 
radiation, while the automatic device uses an indirect differential method to measure the difference between the total and scattered radiation (World Meteorological Organization 2008). According to operating instructions supplied with the device, the CSD3 incorporates three radiation sensors. One measures the total radiation, while the other two provide data on scattered radiation from two different sectors of the sky. These two values (total and scattered radiation) are used to obtain the duration of direct radiation, i.e. sunshine duration. The most important difference between the traditional sunshine recorder and the CSD3 is their sensitivity threshold. Diverse sets of thresholds for the Campbell-Stokes sunshine recorder can be found in literature, $70-280 \mathrm{~W} \mathrm{~m}^{-2}$ (Bider 1958; Baumgartner 1979) and 106-285 $\mathrm{W} \mathrm{m}^{-2}$ (Painter 1981). In Poland, after Kuczmarski (1990), the CS is regarded as beginning recording sunshine at an intensity of $279.2 \mathrm{~W} \mathrm{~m}^{-2}$. In 2003, the WMO established its threshold value at $120 \mathrm{~W} \mathrm{~m}^{-2}$ (World Meteorological Organization 2008), and therefore, this value has been set as the sensitivity threshold in electronic sensors. The Guide to Instruments and Methods of Observation WMO No. 8 gives the following reason for the adoption of $120 \mathrm{~W} \mathrm{~m}^{-2}$ as the threshold value: "Investigations at different stations showed that the threshold irradiance for burning the card varied between 70 and $280 \mathrm{~W} \mathrm{~m}^{-2}$ (Bider 1958; Baumgartner 1979). However, further investigations, especially those performed with the IRSR in France, resulted in a mean value of $120 \mathrm{~W} \mathrm{~m}^{-2}$. This value was finally proposed as the threshold of direct solar irradiance for distinguishing bright sunshine".

This study uses heliographic data and cloud cover observations made at the research station of the Jagiellonian University, Krakow, during the period 2007-2012. The measurement instruments are placed side-by-side on the roof of what is known as the university's historic astronomical observatory, a location which is exposed to sunshine all year round. Detailed metadata of sunshine measurements and the factors influencing changes in sunshine duration values in Krakow can be found in the author's own study (Matuszko 2012b).

A preliminary step in the analysis involved the calculation of daily sunshine durations using data from the CampbellStokes sunshine recorder. Data from the CSD3 sunshine duration sensor, recorded in seconds, were summed up into hourly units and then recalculated into hours and decimal fractions, to mirror the format of the traditional heliogram. The two sets of daily data were then compared, and the associations obtained were presented as figures (Fig. 1) and regression equations for each month compared. Daily cloud cover values were analysed to explain differences in sunshine duration between the two devices. The overall cover and cloud types were observed at three climatological times. In addition, in June and July 2011, wholeday observations of the cloud cover of the Sun were carried out while also recording sunshine duration with both instruments (Matuszko 2012a).

\section{Sunshine duration measurements in Europe today}

In Poland, synoptic stations began measuring sunshine duration with automatic sensors on 1 January 2014. Since 2000, the following countries have made the same switch: Switzerland, the Czech Republic, Iceland and Estonia. A mix of automatic sensors and conventional sunshine recorders (CS) is used in Belgium, Denmark, Luxembourg, Ireland, the UK, Sweden, Germany and the Netherlands. Greece, Croatia and Hungary are still relying solely on the latter type of device (this information is based on unpublished sources from the national weather services of these countries).

In Great Britain, a small number of standard weather stations were replaced with automatic units before 2000, and therefore, measurements of sunshine duration using the Campbell-Stokes sunshine recorder were discontinued. Automatic sunshine sensors were not installed until 2003 following a comparative study that included the calculation of adjustment factors (Kerr and Tabony 2004). The study, however, only used monthly rather than daily data and only covered a period of less than 18 months. The measurement record, both from the CS and AUTO devices, contains numerous gaps found in every month and which are caused, for example, by failure to replace the strip in the Campbell-Stokes sunshine recorder during the weekend. The authors also ignored the difference between the sensitivity thresholds, which they regarded as insignificant. Kerr and Tabony (2004) suggest that more research using much longer records including many types of weather is necessary. The UK's Met Office, however, must be commended for indicating the type of measurement device actually used next to each weather station on the service's official website http://www.metoffice.gov.uk/ climate/uk/stationdata/. This makes the selection of data for climatological analysis easier as it helps to choose stations with homogeneous measurement series and invites caution in making conclusions from heliographic data obtained from different measurement devices.

Only a handful of studies (Kerr and Tabony 2004; Kejna and Uscka-Kowalkowska 2006; Pokorný and Vaníček 2007) compare data from the Campbell-Stokes sunshine recorder and automatic sensors. Also, several national weather services, including Switzerland, Denmark, the Netherlands, UK and Luxembourg, make their reports on sunshine duration measurements available online. Most of these studies mention the existence of differences between the values obtained from different types of devices, but they stop short of explaining the possible causes. They only observe that the introduction of automatic sensors has broken the homogeneity of sunshine measurements and warn against the use of post-2000 data in climatological analyses (Pokorný and Vaníček 2007). 
Fig. 1 Scatter plots of regression obtained from sunshine duration values recorded by a CampbellStokes sunshine recorder (CS) and a CSD3 automatic sensor
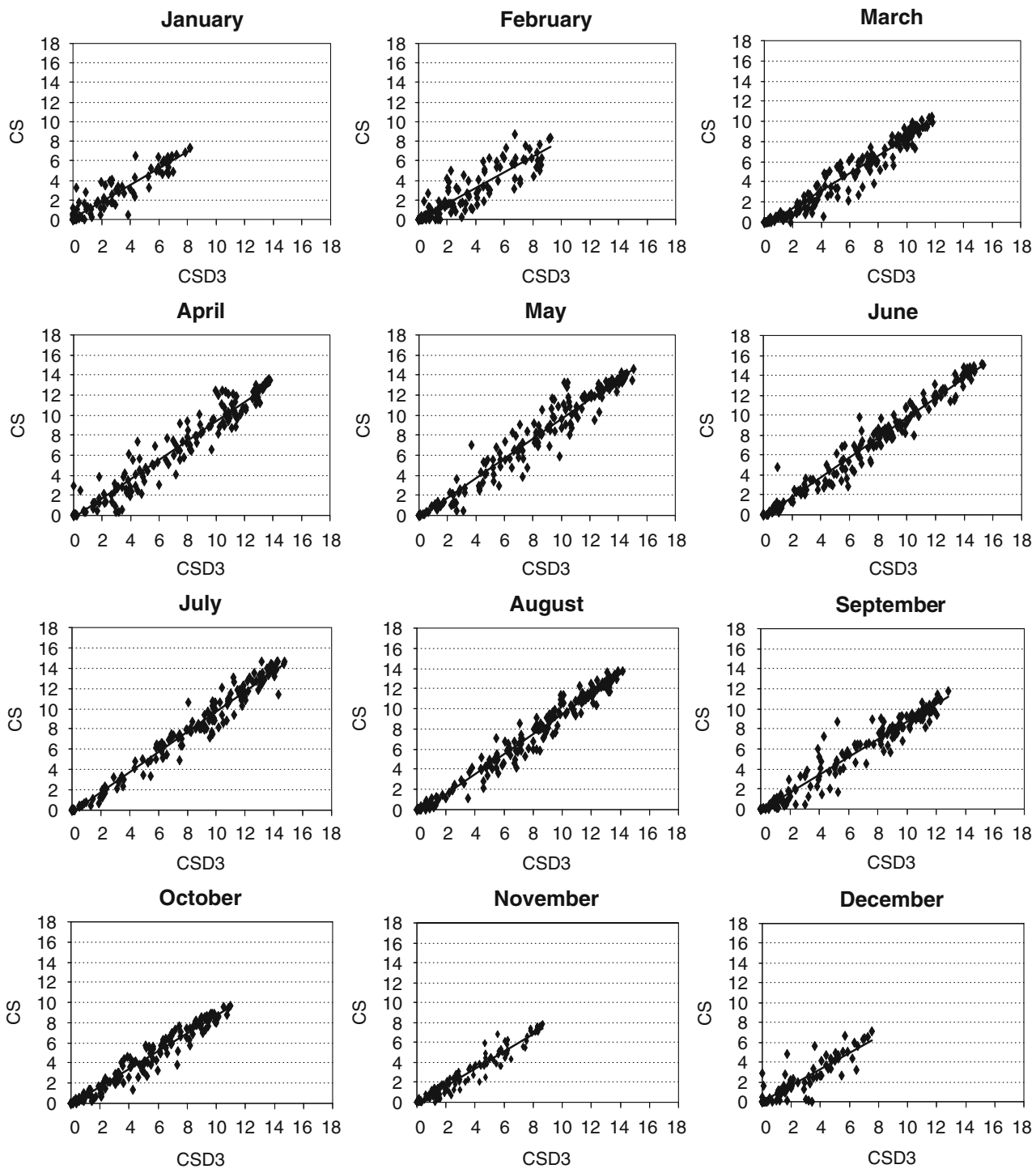

\section{Comparison of sunshine durations from CS and CSD3 measurements}

During the period 2007-2012, the annual average sunshine duration recorded by a CSD3 in Krakow was 164 h or $10.4 \%$ higher than using a CS (Table 1). This difference varied from $115 \mathrm{~h}$ in 2011 to $235 \mathrm{~h}$ in 2008. The largest differences occurred in March and September (Table 1), the two months with the greatest cloud cover variability during the year, and the smallest occurred in January, which can be explained by many partly and fully cloudy days and by the low potential sunshine duration. In relative values, the largest differences (up to $26.7 \%$ ) in the monthly sunshine duration occurred in March and the smallest occurred in July (3.5\%).

In most cases, the range of daily differences in the readouts from the two instruments was less than an hour. Hourly differences (from +0.5 to $-0.5 \mathrm{~h}$ ) account for between $75 \%$ of recorded readouts in December and 34.8\% in March (Table 2). The largest differences $(\geq 2.6$ and $\leq-2.6 \mathrm{~h})$ are relatively rare $(\max 4.3 \%$ in March) and tend to occur in the spring months and in September. The data in Table 2 show a visible seasonality in the differences between the two recording devices. For this reason, it is suggested that separate regression equations should be used when calculating monthly totals of sunshine duration. Table 3 includes equations providing a formula to transform sunshine duration values recorded with the CSD3 (x) to those made with a CS (y).

\section{Attempted explanation of differences}

An analysis of the annual pattern of daily sunshine duration measured in Krakow using the Campbell-Stokes sunshine recorder and the CSD3 sunshine duration sensor revealed that 


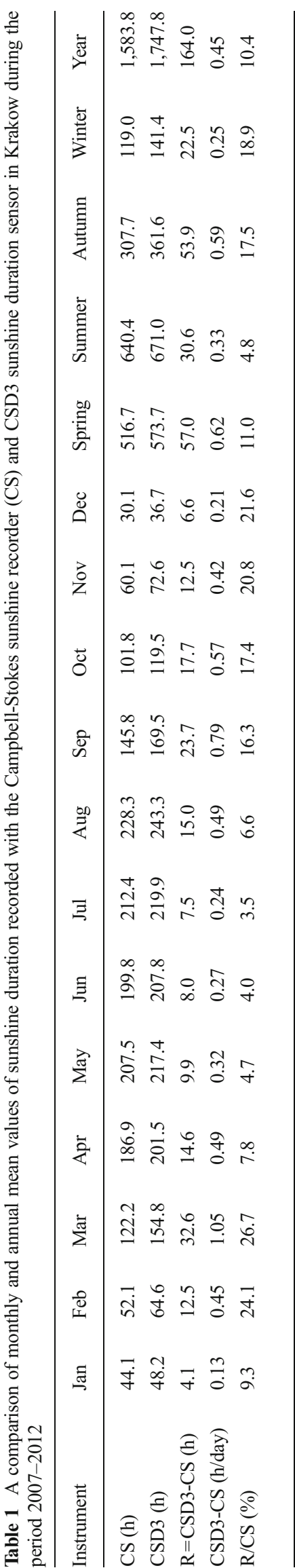

the overall sunshine duration outlooks had similar patterns, but the automatic sensor typically showed higher values, especially on those days with the maximum solar radiation (spring and summer). The latter is explained by the high sensitivity of the automatic sensor, which is capable of recording direct radiation even when clouds briefly receded exposing the Sun's disc, which the traditional sunshine recorder cannot do. A similar effect is noted when the Sun is low over the horizon. Indeed, when the Sun is less than $3-5^{\circ}$ over the horizon, i.e. a short time after sunrise or before sunset, it delivers less than the CS threshold radiation intensity $\left(279.2 \mathrm{~W} \mathrm{~m}^{-2}\right)$, and the heliograph records no sunshine. In this same situation, the electronic sensor already starts to react at a radiation intensity of $120 \mathrm{~W} \mathrm{~m}^{-2}$. For this reason, on cloudless days in the warm half of the year, the CSD3 tends to record nearly $2 \mathrm{~h}$ more sunshine than does the CampbellStokes sunshine recorder. In winter, the Campbell-Stokes sunshine recorder's sphere may be frozen over and record no sunshine on a sunny, but cold day. In autumn and winter, when the Sun is low and predominantly covered by Stratus-type clouds, the CS often fails to register any sunshine while CSD3 does, thus producing sunshine values higher than the traditional instrument.

However, there are also days when the CSD3 records up to $1 \mathrm{~h}$ less sunshine. This is possible when a series of quickly moving Cumulus-type clouds cover and uncover the face of the Sun in rapid succession. A Campbell-Stokes sunshine recorder will show a continuous burned track with a local narrowing (on average $0.9-1.0 \mathrm{~h}$ ), while a CSD3 records less sunshine $(0.6-0.8 \mathrm{~h})$. An even greater difference occurs with more vertically developed clouds, such as Cumulus congestus. In addition, with thick, layered clouds of higher tiers (Altostratus and Cirrostratus), which cause scattered radiation, the Campbell-Stokes sunshine recorder records sunshine while the CSD3 does not. This is due to the low level of direct radiation involved. The latter instrument's design principle means that higher levels of scattered radiation result in lower indicators of sunshine. The effect of Altocumulus translucidus results in sunshine being recorded by the CSD3 and in a thin track on the Campbell-Stokes sunshine recorder's recording strip, but the values indicated by the two instruments are often different.

The greatest differences (both positive and negative) between sunshine duration values measured with the CS and CSD3 occur in the presence of clouds of different tiers (Cirrus, Cirrocumulus, Cirrostratus, Altocumulus, Stratocumulus and Cumulus), especially in spring and in September.

Comparison of the hourly intervals of sunshine duration makes it apparent that the two devices show the highest agreement in summer at midday when the sky is cloudless or only covered by Cirrus clouds. Both instruments also show agreement in recording no sunshine 
Table 2 Frequency (\%) of daily sunshine duration differences between CSD3 and Campbell-Stokes sunshine recorder (CS) in Krakow in the years 2007-2012

\begin{tabular}{|c|c|c|c|c|c|c|c|c|c|c|c|c|c|c|c|c|c|}
\hline Time (h) & Jan & Feb & Mar & Apr & May & Jun & Jul & Aug & Sep & Oct & Nov & Dec & Spring & Summer & Autumn & Winter & Year \\
\hline$\geq 2.6$ & 1.3 & 3.6 & 4.3 & 3.5 & 3.3 & 0.6 & 0.0 & 0.5 & 4.0 & 1.1 & 0.0 & 1.9 & 3.7 & 0.4 & 1.7 & 2.3 & 2.0 \\
\hline $1.6: 2.5$ & 5.2 & 5.9 & 13.6 & 9.9 & 3.3 & 6.9 & 3.5 & 7.6 & 9.6 & 4.9 & 3.3 & 1.3 & 9.0 & 6.1 & 5.9 & 4.2 & 6.3 \\
\hline $0.6: 1.5$ & 16.8 & 18.3 & 25.0 & 25.0 & 16.1 & 16.2 & 11.1 & 22.3 & 23.2 & 23.9 & 18.9 & 9.6 & 22.0 & 16.7 & 22.0 & 15.0 & 19.0 \\
\hline $0.5:-0.5$ & 71.0 & 60.4 & 34.8 & 41.3 & 55.6 & 59.0 & 63.7 & 59.2 & 37.3 & 55.4 & 63.9 & 75.0 & 43.8 & 60.6 & 52.3 & 68.5 & 56.0 \\
\hline$-0.6:-2.5$ & 5.8 & 8.9 & 19.0 & 19.2 & 19.4 & 16.2 & 21.1 & 10.3 & 22.6 & 14.1 & 13.9 & 9.6 & 19.2 & 15.7 & 16.8 & 8.1 & 15.2 \\
\hline$\leq-2.6$ & 0.0 & 3.0 & 3.3 & 1.2 & 2.2 & 1.2 & 0.6 & 0.0 & 3.4 & 0.5 & 0.0 & 2.6 & 2.2 & 0.6 & 1.3 & 1.9 & 1.5 \\
\hline
\end{tabular}

on fully cloudy days with stratus clouds (Altostratus, Stratocumulus or Stratus opacus).

The results obtained in Krakow confirm the finding of Kerr and Tabony (2004) that the greatest differences between the measurements taken by these two instruments occur in the presence of scattered clouds and depend on the elevation of the Sun over the horizon. No differences were found with the Sun high over the horizon during either cloudless or fully cloudy weather. The results are also compatible with patterns described in The Weather Observer's Handbook by Burt (2012), who wrote that when compared to CS, the CSD3 sensor tended to record more sunshine in winter, but less in summer. Pokorný and Vaníček (2007) compared sunshine duration values recorded at Czech weather stations using CS sensors and automatic sensors. Although the automatic instruments used by the Czech weather service (DSU12 SD4 and SD5) were different to those used in Krakow, the authors clearly confirmed that the introduction of automatic sensors broke the homogeneity of the sunshine duration record.

Table 3 Regression equations transforming values of sunshine duration recorded by a CSD3 automatic sensor (x) into values recorded by a Campbell-Stokes sunshine recorder (y), for Krakow in the years 20072012

\begin{tabular}{llll}
\hline Month & Regression equations & $\mathrm{R}^{2}$ & $\mathrm{~s}$ \\
\hline Jan & $\mathrm{y}=0.8481 \mathrm{x}+0.1043$ & 0.8982 & 0.6730 \\
Feb & $\mathrm{y}=0.8018 \mathrm{x}+0.0097$ & 0.8424 & 0.9548 \\
Mar & $\mathrm{y}=0.8644 \mathrm{x}-0.3778$ & 0.9486 & 0.7846 \\
Apr & $\mathrm{y}=0.9594 \mathrm{x}-0.2234$ & 0.9418 & 1.0930 \\
May & $\mathrm{y}=0.9870 \mathrm{x}-0.2335$ & 0.9508 & 1.0720 \\
Jun & $\mathrm{y}=0.9972 \mathrm{x}-0.2580$ & 0.9637 & 0.8775 \\
Jul & $\mathrm{y}=1.0011 \mathrm{x}-0.2730$ & 0.9731 & 0.7772 \\
Aug & $\mathrm{y}=0.9909 \mathrm{x}-0.4188$ & 0.9683 & 0.7545 \\
Sep & $\mathrm{y}=0.8792 \mathrm{x}-0.1095$ & 0.9506 & 0.8752 \\
Oct & $\mathrm{y}=0.8819 \mathrm{x}-0.1181$ & 0.9637 & 0.6075 \\
Nov & $\mathrm{y}=0.8725 \mathrm{x}-0.1082$ & 0.9569 & 0.5034 \\
Dec & $\mathrm{y}=0.8156 \mathrm{x}+0.0090$ & 0.8504 & 0.714 \\
\hline
\end{tabular}

$\mathrm{R}^{2}$ —determination coefficient, $\mathrm{s}$ - standard error of estimation
Similarly, as shown in the study by Kejna and UsckaKowalkowska (2006), monthly and annual sunshine duration values in Krakow are greater from AUTO than from CS sensors. This may also be caused by the specific local conditions in Poland, including a high proportion of stratus clouds and would warrant a further study involving different locations and different weather types. Indeed, all of the studies cited above noted the need for this due to the difficulty of the topic and the need to calculate credible conversion ratios. Obtaining reliable ratios would be very difficult due to the fact that the differences in the sunshine duration values from the two instruments are far from constant and depend on a range of factors, such as the type of clouds, elevation of the Sun and local conditions.

\section{Conclusions}

With the comparison of sunshine duration records from the two recorders, the following conclusions can be derived:

- The replacement of traditional Campbell-Stokes sunshine recorders with electronic sensors produce data that, without comparative research, may suggest an increase in sunshine duration and lead to an erroneous interpretation of the results of temporal and spatial analyses.

- The differences found between sunshine duration values measured with the Campbell-Stokes sunshine recorder (CS) and with the CSD3 sensor resulted from different measurement methodologies and therefore are difficult to compare and explain.

- The over two times lower sensitivity threshold of the CSD3 in comparison with the CS causes the faster reaction of the electronic sensor to solar radiation, especially within an hour after sunrise and before sunset, as well as during a brief exposure of the Sun's disc on very cloudy days.

- Differences in sunshine duration values (both positive and negative) depend on the scale and type of clouds, but not on the overall cloudiness. 
- Despite the indisputable imperfections in the recording of sunshine and in the interpretation of heliograms, the CS remains the best instrument for sunshine measurement since it allows the analysis of long-term heliographic data series.

- The results of the study indicate the need for the continuation of research which includes the application of parallel measurements using both traditional and automatic instruments.

Open Access This article is distributed under the terms of the Creative Commons Attribution License which permits any use, distribution, and reproduction in any medium, provided the original author(s) and the source are credited.

\section{References}

Baumgartner T (1979) Die Schwellenintensitat des Sonnenscheinautographen Campbell-Stokes an wolkenlosen Tagen. Arbeitsberichte der Schweizerischen Meteorologischen Zentralanstalt 84 Zurich

Bider M (1958) Uber die Genauigkeit der Registrierungen des Sonnenscheinautographen Campbell-Stokes. Archiv fur Meteorologie Geophysik und Bioklimatologie Serie B 9(2):199-230

Burt S (2012) The Weather Observer's Handbook. Cambridge, New York

Kejna M, Uscka-Kowalkowska J (2006) Porównanie wyników pomiarów meteorologicznych w Stacji ZMŚP w Koniczynce (Pojezierze Chełmińskie) wykonanych metodą tradycyjną i automatyczną w roku hydrologicznym 2002 (A comparison of traditional and automatic measurements at the Koniczynka Weather Station (Chełmińskie Lakeland, Northern Poland), during the hydrological year 2002). Annales Universitates Mariae CurieSkłodowska Sec B 24:208-217 (in Polish)

Kerr A, Tabony R (2004) Comparison of sunshine recorded by Campbell-Stokes and automatic sensors. Weather 59(4):90-95

Kuczmarski M (1990) Usłonecznienie Polski i jego przydatność dla helioterapii (Sunshine duration in Poland and its use for heliotherapy). Dokumentacja Geograficzna 4:67 (in Polish)

Matuszko D (2012a) Porównanie wartości usłonecznienia mierzonego heliografem Campbella-Stokesa i czujnikiem elektronicznym CSD3 (A comparison of sunshine duration values measured with the Campbell-Stokes sunshine recorder and the CSD3 electronic sensor). Przegląd Geofizyczny 1:3-10 (in Polish)

Matuszko D (2012b) Influence of cloudiness on sunshine duration. Int J Climatol 32:1527-1536

Painter HE (1981) The performance of a Campbell-Stokes sunshine recorder compared with a simultaneous record of normal incidence irradiance. Meteorol Mag 110:102-109

Pokorný J, Vaníček K (2007) Automatizace měření slunečního svitu na stanicích Českého hydrometeorologického ústavu pomocí elektronických slunoměrů. Meteorologické zprávy 60(4):106-116

Stanhill G (2003) Through a glass brightly: some new light on the Campbell-Stokes sunshine recorder. Weather 58:3-11

World Meteorological Organization (1962) Abridged Final Report of the Third Session of the Commission for Instruments and Methods of Observation

World Meteorological Organization (2008) Guide to Meteorological Instruments and Methods of Observation: (CIMO guide). WMONo.8 Secretariat of the WMO Geneva http://www.metoffice.gov.uk/ climate/uk/stationdata/ Accessed 26 June 2013 